\title{
First Cytogenetic Study of Green Chromis, Chromis viridis (Perciformes, Pomacentridae) by Conventional Staining and Ag-NOR Banding Techniques
}

\section{Nuntaporn Getlekha $^{1^{*}}$ and Alongklod Tanomtong ${ }^{2}$}

\begin{abstract}
${ }^{1}$ Department of Biology, Faculty of Science and Technology, Muban Chombueng Rajabhat University, Ratchaburi 70150, Thailand

${ }^{2}$ Toxic Substances in Livestock and Aquatic Animals Research Group, Department of Biology, Faculty of Science, Khon Kaen University, Khon Kaen 40002, Thailand
\end{abstract}

*Corresponding author. E-mail: taapu_getlekha@hotmail.com https://doi.org/10.12982/CMUJNS.2020.0011

Received: January 18, 2018

Revised: March 7, 2019

Accepted: June 17, 2019

\begin{abstract}
This work represents the first cytogenetics analysis conducted on the green chromis, Chromis viridis (Cuvier, 1830) from Thailand. Mitotic chromosomes were prepared from the anterior kidney. The cell suspensions were harvested by in vivo colchicine treatment. The slides were prepared by conventional air-drying method. Chromosomes were analyzed after the conventional and Ag-NOR staining techniques. The results showed that $C$. viridis has $2 n=48$ (48t), the fundamental number (NF) was 48 and no heteromorphic sex chromosomes were indentified. NORs were located on subcentomeric region of long arms of the $6^{\text {th }}$ telocentric chromosome pair.
\end{abstract}

Keywords: Chromosome, Karyotype, Nucleolar organizer region, Damselfishes, Perciformes

\section{INTRODUCTION}

The family Pomacentridae belongs to order Perciformes which includes the damselfishes and clownfishes (Nelson, 2006). Around 385 species distributed in 28 genera are classified in this family (Allen, 1991, 1997). Pomacentrid fishes are usually found in tropical seas, with only a few species being found in temperate waters. The highest abundance of species is found on coral reefs in the IndoWest-Pacific region. Especially, the greatest concentration of species is found on the area from the Philippines to Australia hosts. The remaining species are found 
in the Atlantic or eastern Pacific, while few ones are native species on freshwater or brackish water surroundings (Allen, 1991).

Table 1. Cytogenetic reviews of the subfamily Chominae (Pomacentridae).

\begin{tabular}{|c|c|c|c|c|c|c|c|}
\hline No. & Subfamily/Species & $2 n$ & $\mathbf{N F}$ & NORs & Formula & Locality & Reference \\
\hline 1 & Chromis caerulea & 48 & 48 & - & $48 \mathrm{t}$ & Japan & $\begin{array}{l}\text { Ojima and Kashiwagi } \\
\text { (1981) }\end{array}$ \\
\hline 2 & C. chromis & 48 & 48 & - & $48 \mathrm{t}$ & $\begin{array}{l}\text { Spain } \\
\text { (Malaga) }\end{array}$ & Alvarez et al. (1980) \\
\hline 3 & C. chrysura & 48 & 50 & - & $2 m+46 t$ & Japan & Ojima (1983) \\
\hline 4 & C. flavicauda & 39 & 54 & 2 & $9 m+6 s m+24 t$ & Brazil (ES) & $\begin{array}{l}\text { Molina and Galetti } \\
\text { (2002) }\end{array}$ \\
\hline \multirow[t]{2}{*}{5} & C. insolata & 47 & 56 & 2 & $3 m+6 s m+38 t$ & Brazil (ES) & $\begin{array}{l}\text { Molina and Galetti } \\
\text { (2002) }\end{array}$ \\
\hline & C. insolata & 46 & 56 & 2 & $4 m+6 s m+36 t$ & Brazil (ES) & $\begin{array}{l}\text { Molina and Galetti } \\
\text { (2002) }\end{array}$ \\
\hline 6 & C. multilineata & 48 & 48 & 2 & $48 \mathrm{t}$ & Brazil (BA) & $\begin{array}{l}\text { Molina and Galetti } \\
\text { (2002) }\end{array}$ \\
\hline 7 & C. ternatensis & 48 & 48 & - & $48 \mathrm{t}$ & Pacific & Takai and Ojima (1999) \\
\hline 8 & C. viridis & 48 & 48 & 2 & $48 t$ & $\begin{array}{l}\text { Gulf of } \\
\text { Thailand }\end{array}$ & Present study \\
\hline 9 & Dascyllus abudafur & 48 & 50 & 2 & $2 a+46 t$ & $\begin{array}{l}\text { Gulf of } \\
\text { Thailand }\end{array}$ & Getlekha, N. (2017) \\
\hline \multirow[t]{10}{*}{10} & D. aruanus & 33 & 48 & - & $15 \mathrm{~m} / \mathrm{sm}+18 \mathrm{t}$ & S. Japan & $\begin{array}{l}\text { Ojima and Kashiwagi } \\
\text { (1981) }\end{array}$ \\
\hline & & 32 & 48 & - & $16 \mathrm{~m} / \mathrm{sm}+16 \mathrm{t}$ & S. Japan & $\begin{array}{l}\text { Ojima and Kashiwagi } \\
\text { (1981) }\end{array}$ \\
\hline & & 32 & 48 & 2 & $16 \mathrm{~m} / \mathrm{sm}+16 \mathrm{t}$ & S. Japan & Kashiwagi et al. (2005) \\
\hline & & 31 & 48 & - & $17 \mathrm{~m} / \mathrm{sm}+14 \mathrm{t}$ & S. Japan & $\begin{array}{l}\text { Ojima and Kashiwagi } \\
\text { (1981), Kashiwagi et al. } \\
\text { (2005) }\end{array}$ \\
\hline & & 30 & 48 & - & $18 \mathrm{~m} / \mathrm{sm}+12 \mathrm{t}$ & S. Japan & $\begin{array}{l}\text { Ojima and Kashiwagi } \\
\text { (1981), Kashiwagi et al. } \\
\text { (2005) }\end{array}$ \\
\hline & & 30 & 50 & 2 & $18 \mathrm{~m}+2 \mathrm{st}+10 \mathrm{t}$ & $\begin{array}{l}\text { Gulf of } \\
\text { Thailand }\end{array}$ & Getlekha et al. (2016) \\
\hline & & 29 & 48 & - & $19 \mathrm{~m} / \mathrm{sm}+10 \mathrm{t}$ & S. Japan & $\begin{array}{l}\text { Ojima and Kashiwagi } \\
\text { (1981), Kashiwagi et al. } \\
\text { (2005) }\end{array}$ \\
\hline & & 28 & 48 & - & $20 \mathrm{~m} / \mathrm{sm}+8 \mathrm{t}$ & S. Japan & $\begin{array}{l}\text { Ojima and Kashiwagi } \\
\text { (1981) }\end{array}$ \\
\hline & & 28 & 48 & 2 & $20 \mathrm{~m} / \mathrm{sm}+8 \mathrm{t}$ & S. Japan & Kashiwagi et al. (2005) \\
\hline & & 27 & 48 & - & $21 \mathrm{~m} / \mathrm{sm}+6 \mathrm{t}$ & S. Japan & $\begin{array}{l}\text { Ojima and Kashiwagi } \\
\text { (1981) }\end{array}$ \\
\hline 11 & D. carneus & 48 & 50 & 2 & $2 a+46 t$ & $\begin{array}{l}\text { Gulf of } \\
\text { Thailand }\end{array}$ & Getlekha et al. (2016) \\
\hline \multirow[t]{3}{*}{12} & D. melanurus & 48 & 48 & - & $48 \mathrm{t}$ & S. Japan & $\begin{array}{l}\text { Ojima and Kashiwagi } \\
\text { (1981) }\end{array}$ \\
\hline & & 48 & 48 & 2 & $48 \mathrm{t}$ & S. Japan & Kashiwagi et al. (2005) \\
\hline & & 48 & 50 & 2 & $2 a+46 t$ & $\begin{array}{l}\text { Indian } \\
\text { Ocean }\end{array}$ & Getlekha et al. (2016) \\
\hline
\end{tabular}

Note: $2 n=$ diploid chromosome number, $\mathrm{NF}=$ fundamental number (number of chromosome arm), $\mathrm{m}=$ metacentric, $\mathrm{sm}=$ submetacentric, $\mathrm{a}=$ acrocentric, $\mathrm{t}=$ telocentric chromosome, NORs $=$ nucleolar organizer regions and $-=$ not available. 
Table 1. Cont.

\begin{tabular}{|c|c|c|c|c|c|c|c|}
\hline No. & Subfamily/Species & $2 n$ & NF & NORs & Formula & Locality & Reference \\
\hline \multirow[t]{3}{*}{13} & D. reticulatus & 36 & 48 & 2 & $12 \mathrm{~m} / \mathrm{sm}+24 \mathrm{t}$ & S. Japan & $\begin{array}{l}\text { Hardie and Hebert } \\
\text { (2004), Kashiwagi } \\
\text { et al. (2005) }\end{array}$ \\
\hline & & 35 & 48 & - & $13 \mathrm{~m} / \mathrm{sm}+22 \mathrm{t}$ & S. Japan & $\begin{array}{l}\text { Ojima and } \\
\text { Kashiwagi (1981), } \\
\text { Kashiwagi et al. } \\
\text { (2005) }\end{array}$ \\
\hline & & 34 & 48 & - & $14 \mathrm{~m} / \mathrm{sm}+20 \mathrm{t}$ & S. Japan & $\begin{array}{l}\text { Ojima and } \\
\text { Kashiwagi (1981) }\end{array}$ \\
\hline \multirow[t]{5}{*}{14} & D. trimaculatus & 48 & 48 & - & $48 \mathrm{t}$ & S. Japan & $\begin{array}{l}\text { Ojima and } \\
\text { Kashiwagi (1981), } \\
\text { Hardie and Hebert } \\
\text { (2004) }\end{array}$ \\
\hline & & 48 & 48 & 2 & $48 \mathrm{t}$ & S. Japan & $\begin{array}{l}\text { Kashiwagi et al. } \\
(2005)\end{array}$ \\
\hline & & 47 & 48 & - & $1 \mathrm{~m}+46 \mathrm{t}$ & Japan & $\begin{array}{l}\text { Arai and Inoue } \\
\text { (1976), Kashiwagi } \\
\text { et al. (2005) }\end{array}$ \\
\hline & & 48 & 50 & 2 & $2 s t+46 t$ & $\begin{array}{l}\text { Gulf of } \\
\text { Thailand }\end{array}$ & $\begin{array}{l}\text { Getlekha et al. } \\
\text { (2016) }\end{array}$ \\
\hline & & 48 & 50 & 2 & $2 a+46 t$ & $\begin{array}{l}\text { Gulf of } \\
\text { Thailand }\end{array}$ & $\begin{array}{l}\text { Getlekha et al. } \\
\text { (2017) }\end{array}$ \\
\hline
\end{tabular}

Note: $2 n$ = diploid chromosome number, $\mathrm{NF}=$ fundamental number (number of chromosome arm), $\mathrm{m}=$ metacentric, $\mathrm{sm}=$ submetacentric, $\mathrm{a}=$ acrocentric, $\mathrm{t}=$ telocentric chromosome, $\mathrm{NORs}=$ nucleolar organizer regions and $-=$ not available.

Out of 385 described species of Pomacentridae, only 49 species have been karyologically investigated (Arai, 2011). The study reports that less than $13 \%$ of the number of species of damselfishes has been currently analyzed, inclusion only 7 species of the genus Chromis, However, despite this few number, karyotypes involved in Robertsonian rearrangements with diploid chromosomes less than $2 \mathrm{n}=48$ and large bi-armed chromosomes were found in two Chromis species (Molina and Galetti, 2002). In the other analyzed species, the diploid number were 46 and 47 in C. insolata, both the NF being 56, 2n=39 in C. flavicauda, the fundamental numbers (NF) presenting 54 while most of them (five species) had $2 \mathrm{n}=48$ chromosomes and the NF ranged from 48 to 50 in C. caerulea, C. chromis, C. chrysura, C. multilineata and C. ternatensis. (Alvarez et al., 1980; Ojima and Kashiwagi, 1981; Ojima, 1983; Takai and Ojima, 1999; Molina and Galetti, 2002). Another three species of Dascyllus showed inter- and intraspecific Robertsonian polymorphism: the diploid chromosome numbers were $2 \mathrm{n}=47$ and 48 in D. trimaculatus, $2 \mathrm{n}=34,35,36$, and 37 in D. reticulatus, $2 \mathrm{n}=27,28,29,30$, 31,32 and 33 in D. aruanus, and $2 \mathrm{n}=48$ in D. melanurus, these NF presenting 48 in all specimens. (Ojima and Kashiwagi, 1981).

In this research, we analyzed the standard karyotype, idiogram and NORs sites in $C$. viridis population from Thailand. This species was chosen for this study to extend the existing information on the family Pomacentridae for support taxonomy of genus Chromis. 


\section{MATERIALS AND METHODS}

\section{Specimens collected}

The green chromis species were analyzed: Chromis viridis (Cuvier, 1830) (8 males and 10 females) from the Gulf of Thailand (Pacific Ocean) (Figure 1). The specimens were caught using hand-net. After captured, the specimens were then kept in sealed plastic bags containing oxygen and transported to the research station. The specimens were deposited in the fish collection of the Cytogenetic Laboratory, Department of Biology, Faculty of Science, Khon Kaen University.

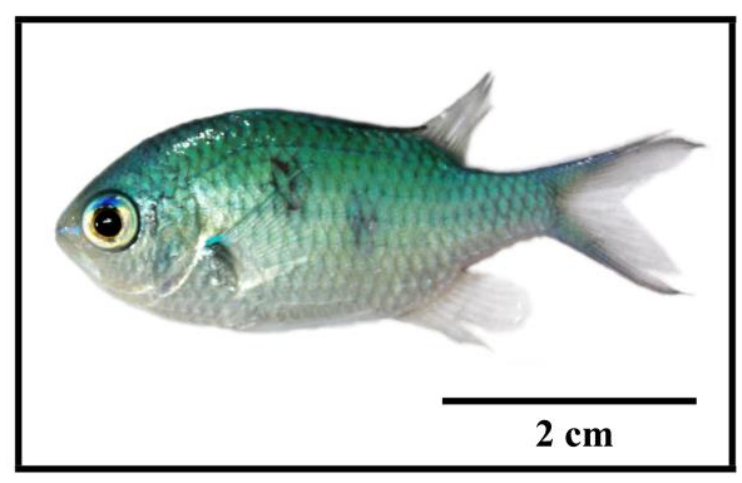

Figure 1. General characteristic of male green chromis, Chromis viridis.

\section{Chromosome preparation}

All the experiments followed ethical protocols and anesthesia with ice prior to sacrifice. Chromosomes were prepared from the cell suspensions of the anterior kidney. Briefly, the $0.01 \%$ colchicine was injected into its abdominal cavity for $1 \mathrm{~h}$. The kidney tissue was taken off and gently minored in hypotonic solution $(0.075 \mathrm{M} \mathrm{KCl})$ and then incubated for $30 \mathrm{~min}$. The cell suspensions were then fixed in Carnoy's fixative solution (ratio 3 methanol: 1 acetic acid). The cell suspensions were dropped on the slide (Getlekha et al., 2017; Kasiroek et al., 2017; Supiwong et al., 2017).

\section{Chromosome staining}

Conventional staining technique. The slides were dipped into a copling jar containing 20\% Giemsa's solution and left for 10 minutes. After that, they were rinsed in distilled water and left for air-drying (Rooney, 2001).

Ag-NOR banding technique. The 50\% silver nitrate and 2\% gelatin (ratio 2: 1 , respectively) were dropped on slides. The slide was mounted with cover glass and incubated at $60^{\circ} \mathrm{C}$ for $8 \mathrm{~min}$. The slide was then rinsed with distilled water until cover glass is seceded. After that, the slides were left for air-drying (Howell and Black, 1980).

\section{Chromosome checking, karyotyping and idiograming}

Image processing, to determine the diploid chromosome numbers, karyotype and idiogram structures were made based on at least 20 metaphase 
spreads. Images were taken using a light microscope connects with Canon EOS 550D DSLR camera and were organized using Photoshop. Chromosomes were classified as metacentric (m), submetacentric ( $\mathrm{sm}$ ), acrocentric (a) and telocentric (t) according to their arm ratios (Turpin and Lejeune, 1965).

Idiogram is a diagram representation of a chromosomal karyotype of a haploid set $(n)$ which includes autosomes and sex chromosomes, showing the number and morphological characteristics of chromosomes of a species. The average length of chromosomes, the type of chromosome and the centromere region were used for idiogram structuring (Tanomtong, 2011).

\section{RESULTS}

Cytogenetic analyses were conducted on $C$. viridis from the Gulf of Thailand (Indo-Pacific). The $2 \mathrm{n}$ of $C$. viridis is 48 chromosomes in all specimens, with karyotypes predominantly formed by telocentric chromosomes (Figure 2, 3 and Table 2). The NF of $C$. vilidis was 48 in both sexes and the karyotype comprises 48 telocentric chromosomes (48 mono-armed chromosomes) (Figure 4). Ag-NOR sites were detected on the subcentromeric portion of the long arms of the no. $6^{\text {th }}$ telocentric pair in $C$. viridis (Figure 3). The karyotypes of $C$. viridis by Geimsa's staining and Ag-NOR staining techniques are depicted in Figures 2 and 3 . The idiogram of $C$. viridis represent gradually declining length of the chromosomes (Figure 4). The important karyotype feature is the predominately with telocentric chromosome, which was found in all telocentric chromosomes. The karyotype formula of $C$. viridis is as follow: $2 n(48)=48 \mathrm{t}$
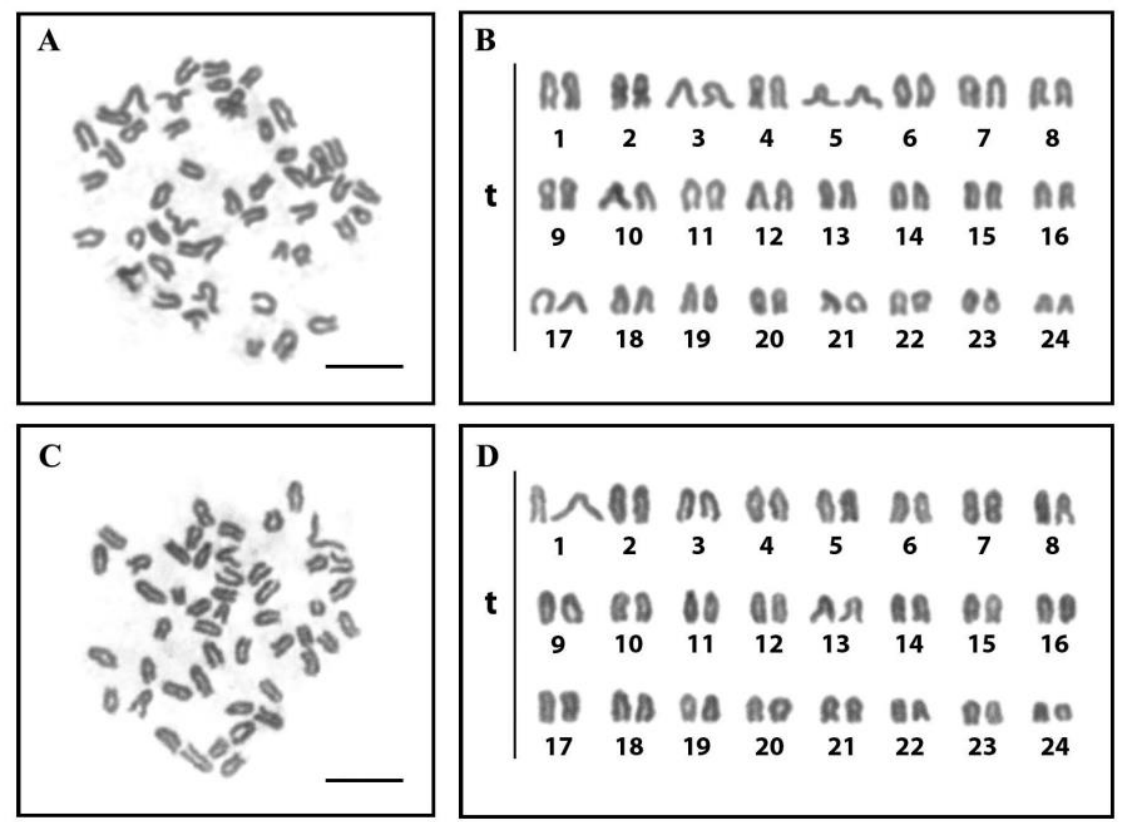

Figure 2. Metaphase chromosome plates and karyotypes of male (A and B) and female (C and D) of the green chromis (Chromis viridis, $2 n=48$ ) by conventional staining (scale bars indicate $10 \mu \mathrm{m}$ ). 

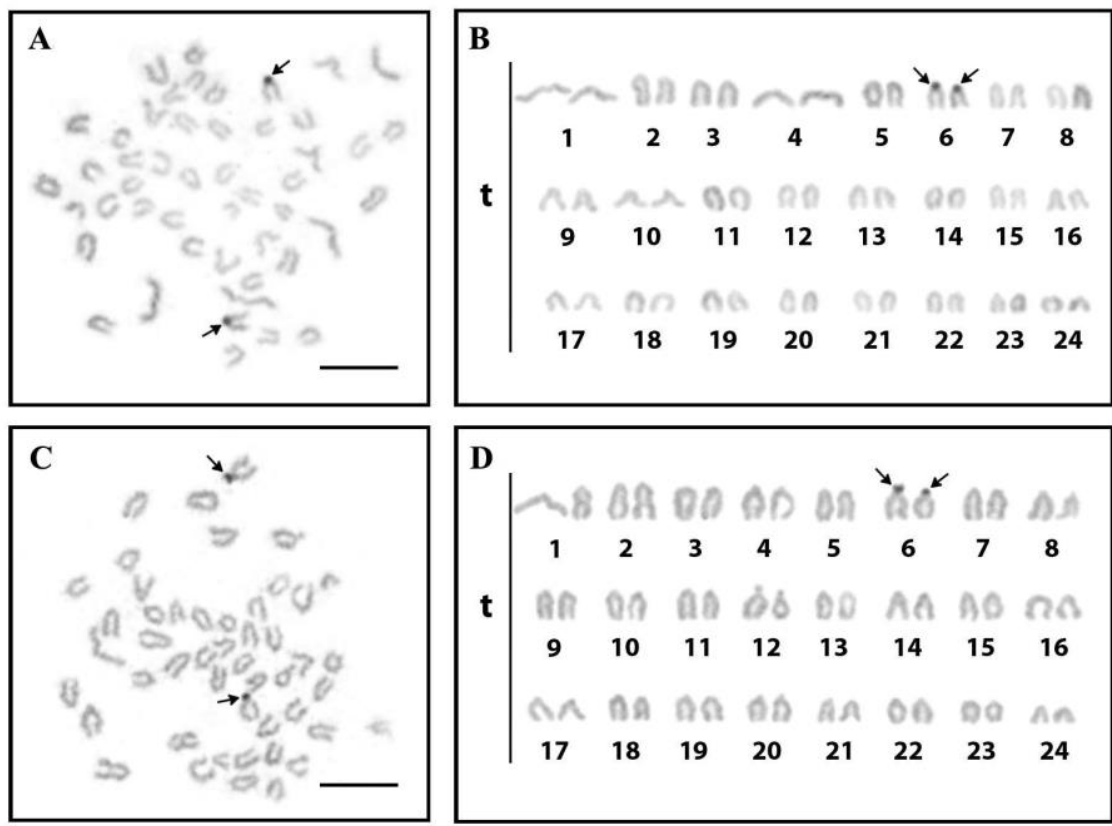

Figure 3. Metaphase chromosome plates and karyotypes of male (A and B) and female $(\mathrm{C}$ and $\mathrm{D})$ of the green chromis (Chromis viridis, $2 n=48)$ by Ag-NOR banding technique; scale bars indicate $10 \mu \mathrm{m}$. The subcentromeric region of telocentric chromosome pair 6 showed clearly observable nucleolar organizer regions (NORs) (arrows).

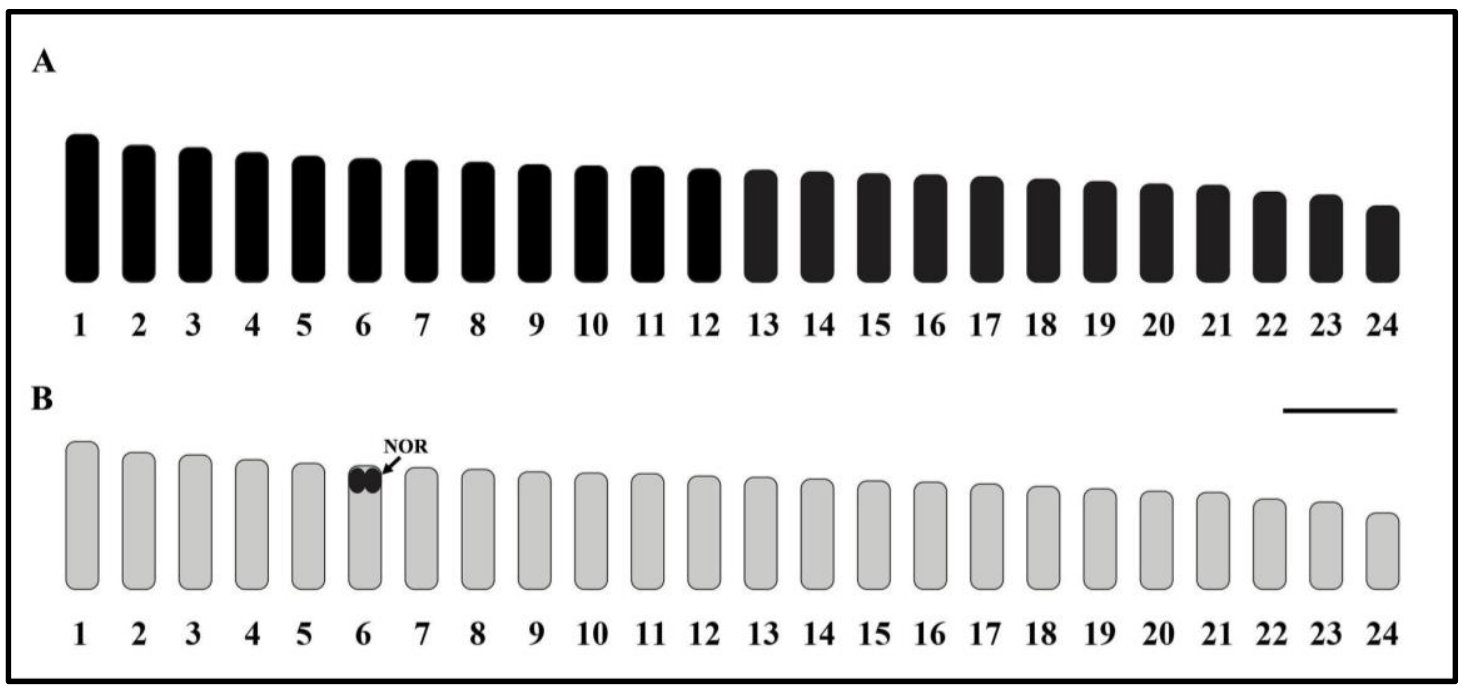

Figure 4. Standardized idiogram showing lengths and shapes of chromosomes of the green chromis (Chromis viridis, $2 n=48$ ) by conventional staining and Ag-NOR banding techniques; scale bars indicate $2 \mu \mathrm{m}$. The arrow indicates nucleolar organizer regions. 
Table 2. Mean length of short arm chromosome (Ls), length long arm chromosome (Ll), length total arm chromosome (LT), relative length $(\mathrm{RL})$, centromeric index (CI) and standard deviation (SD) of RL, CI from 20 metaphase cells of the male and female the green chromis (Chromis viridis), $2 n=48$.

\begin{tabular}{ccccccc}
\hline $\begin{array}{c}\text { Chromosome } \\
\text { pair }\end{array}$ & Ls & Ll & LT & RL \pm SD & CI \pm SD & $\begin{array}{c}\text { Chromosome } \\
\text { type }\end{array}$ \\
\hline 1 & 0.00 & 2.44 & 2.44 & $0.0558 \pm 0.0043$ & $1.0000 \pm 0.0000$ & telocentric \\
2 & 0.00 & 2.26 & 2.26 & $0.0519 \pm 0.0030$ & $1.0000 \pm 0.0000$ & telocentric \\
3 & 0.00 & 2.22 & 2.22 & $0.0507 \pm 0.0028$ & $1.0000 \pm 0.0000$ & telocentric \\
4 & 0.00 & 2.14 & 2.14 & $0.0481 \pm 0.0013$ & $1.0000 \pm 0.0000$ & telocentric \\
5 & 0.00 & 2.08 & 2.08 & $0.0478 \pm 0.0013$ & $1.0000 \pm 0.0000$ & telocentric \\
$6^{*}$ & 0.00 & 2.04 & 2.04 & $0.0469 \pm 0.0013$ & $1.0000 \pm 0.0000$ & telocentric \\
7 & 0.00 & 2.01 & 2.01 & $0.0452 \pm 0.0014$ & $1.0000 \pm 0.0000$ & telocentric \\
8 & 0.00 & 1.98 & 1.98 & $0.0444 \pm 0.0011$ & $1.0000 \pm 0.0000$ & telocentric \\
9 & 0.00 & 1.94 & 1.94 & $0.0447 \pm 0.0006$ & $1.0000 \pm 0.0000$ & telocentric \\
10 & 0.00 & 1.92 & 1.92 & $0.0431 \pm 0.0005$ & $1.0000 \pm 0.0000$ & telocentric \\
11 & 0.00 & 1.91 & 1.91 & $0.0439 \pm 0.0008$ & $1.0000 \pm 0.0000$ & telocentric \\
12 & 0.00 & 1.87 & 1.87 & $0.0420 \pm 0.0008$ & $1.0000 \pm 0.0000$ & telocentric \\
13 & 0.00 & 1.85 & 1.85 & $0.0414 \pm 0.0010$ & $1.0000 \pm 0.0000$ & telocentric \\
14 & 0.00 & 1.82 & 1.82 & $0.0419 \pm 0.0010$ & $1.0000 \pm 0.0000$ & telocentric \\
15 & 0.00 & 1.79 & 1.79 & $0.0401 \pm 0.0009$ & $1.0000 \pm 0.0000$ & telocentric \\
16 & 0.00 & 1.77 & 1.77 & $0.0406 \pm 0.0010$ & $1.0000 \pm 0.0000$ & telocentric \\
17 & 0.00 & 1.74 & 1.74 & $0.0391 \pm 0.0013$ & $1.0000 \pm 0.0000$ & telocentric \\
18 & 0.00 & 1.70 & 1.70 & $0.0382 \pm 0.0009$ & $1.0000 \pm 0.0000$ & telocentric \\
19 & 0.00 & 1.66 & 1.66 & $0.0373 \pm 0.0012$ & $1.0000 \pm 0.0000$ & telocentric \\
20 & 0.00 & 1.62 & 1.62 & $0.0363 \pm 0.0010$ & $1.0000 \pm 0.0000$ & telocentric \\
21 & 0.00 & 1.60 & 1.60 & $0.0367 \pm 0.0016$ & $1.0000 \pm 0.0000$ & telocentric \\
22 & 0.00 & 1.49 & 1.49 & $0.0334 \pm 0.0015$ & $1.0000 \pm 0.0000$ & telocentric \\
23 & 0.00 & 1.44 & 1.44 & $0.0321 \pm 0.0022$ & $1.0000 \pm 0.0000$ & telocentric \\
24 & 0.00 & 1.26 & 1.26 & $0.0281 \pm 0.0026$ & $1.0000 \pm 0.0000$ & telocentric \\
\hline
\end{tabular}

Note: * NOR-bearing chromosome.

\section{DISCUSSION}

\section{Chromosome number, fundamental number and karyotype of $C$. viridis}

The diploid chromosome number of $C$. viridis is 48 chromosomes with chromosomes predominantly formed by telocentric chromosomes similar to the other species in the genus Chromis, and the morphologically differentiated sex chromosome could not be observed (Alvarez et al., 1980; Ojima and Kashiwagi, 1981; Ojima, 1983, Takai and Ojima, 1999; Molina and Galetti, 2002) (Table 1). Such chromosome pattern represents the basal form of the order Perciformes and it has been detected on most species of this order (Ohno, 1970). In addition, it differs from reports of Molina and Galetti (2002) that reported the 2n of 46-47 and 39 in C. insolata and C. flavicauda, respectively (Table 1), indicating the 
occurrence of chromosomal rearrangements during the karyotype evolution of these groups.

The fundamental number of $C$. vilidis was 48 (48 mono-armed chromosomes) agreement with the data of the genus Chromis in the previous studies that pointed a $\mathrm{NF}=48$ in $C$. caerulea, C. chromis, C. multilineata and C. ternatensis (Alvarez et al., 1980; Ojima and Kashiwagi, 1981; Takai and Ojima, 1999; Molina and Galetti, 2002) demonstrating a highly conserved karyotype occurring in these fishes. The other species in the genus Chromis have higher NF, for example $C$. chrysura with $\mathrm{NF}=50$ (Ojima, 1983), C. flavicauda with $\mathrm{NF}=54$ and $C$. insolata with $\mathrm{NF}=56$ (Molina and Galetti, 2002). The occurrence of higher NF suggests the occurrence of pericentric inversion events.

\section{Chromosome markers of $C$. viridis}

Nucleolar organizer region is the secondary constriction being found on chromosomes in addition to primary constriction (centromere) and includes the genes for rRNA synthesis (18S, 5S and 28S). This constriction stained by the silver staining in order to visualize the nucleolar organizing regions (Ag-NORs), indicating NORs. The NORs of sharing at the subcentromeric region on telocentric chromosomes of $C$. viridis rather resembled to the scattering form that spotted in other Chrominae species (Takai and Ojima, 1995). The result differences from NORs of the $C$. insolata, the NOR regions are located in nonhomologous chromosomes in both species (Molina and Galetti, 2002). Moreover, in $C$. flavicauda, NOR sites were present on the telomeric portion of distinct chromosomal pairs. One site was detected on the long arms of a small submetacentric chromosome no. 7 , while another one was located on the short arms of a small acrocentric chromosome no. 18. This may reveal that chromosomal rearrangement may have occurred on these fishes, leading to widespread chromosomal polymorphism. (Molina and Galetti, 2002) (Figure 5).

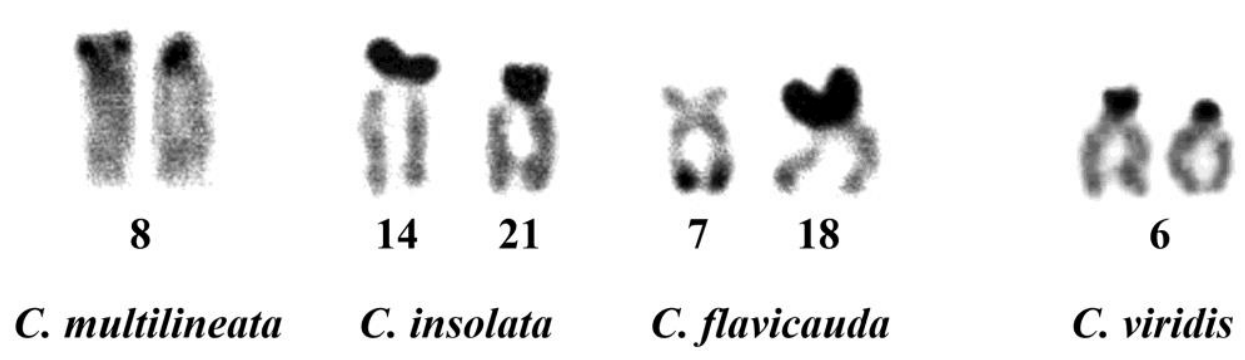

Molina and Galetti (2002)

Present study

Figure 5. A comparison of the nucleolar organizer regions (NORs) of Chromis species. 


\section{Chromosome evolution of the Chrominae subfamily}

Chromosomal rearrangements represent the main cause of karyotype diversification among several Perciformes species (Molina and Galetti, 2002). Most Pomacentridae fishes display a conserved $2 n=48$, but vary in their fundamental number $(\mathrm{NF}=48-90)$ possibly due to the occurrence of pericentric inversions (Takai and Ojima, 1987). On the other hand, Chrominae displays a particular tendency concerning Robertsonian rearrangements such as those observed in D. trimaculatus $(2 n=47-48)$, in D. reticulatus $(2 n=34-37)$ and in D. aruanus (2n=27-33) (Ojima and Kashiwagi, 1981). In common, the possibility of different cytotypes in among these fishes is related to the presence of multiple sex chromosomes because they are asynchronic hermaphrodits (Ojima and Kashiwagi, 1981).

Fish species of inter-oceanic distribution, from the Caribbean reefs and from the Gulf of California in the Pacific Ocean, had a Pleistocene radiation (Shulman and Bermingham, 1995; Ward, 1995), demonstrating that the changes that occurred during this time are strict enough to affect distinct groups depend on a wide or narrow ability of migration (Goodbred and Graves, 1996).

From the previous cytogenetic study. The conservation of karyotype patterns among these fishes can be revealed on Table 1 . The centric fusion is the main cause of the reduction of the $2 n$ and the occurrence of distinctive metacentric chromosomes in C. insolata and C. flavicauda (Molina and Galetti, 2002). In Chrominae species may present karyotypic orthoselection that polymorphism could be temporary and represent an evolutionary process in each step (White, 1973). Other fish species represent chromosomal pattern similar to Chromis. In the interphase period, may be configured that could have help chromosomal exchange among non-homologous chromosomes during a later arrangement of these chromosomes (Aguilar et al., 1998).

\section{CONCLUSION}

Based on the chromosome study of the green chromis ( $C$. viridis) using conventional staining and NOR banding techniques can verify diploid chromosome, fundamental number and size of chromosome. The results showed that $C$. viridis has $2 n=48$ predominantly with telocentric chromosome, the fundamental number (NF) was 48. The Ag-NORs sites were located on the subcentomeric region of long arms of the telocentric chromosome pair no. $6^{\text {th }}$. The idiogram of $C$. viridis represent gradually declining length of the chromosomes. The important karyotype feature is the predominately with telocentric chromosome, which was found in all telocentric chromosomes like a common ancestor of marine fish concern with high ability of distribution, as a result high gene flow and low chromosome evolution. The karyotype formula of C. viridis is as follow: $2 n(48)=48 \mathrm{t}$ 
Up to the present, there are 8 species of the Genus Chromis cytogenetically analyzed. Chromis species provides remarkable karyotype features for chromosome evolutionary discussion. Further studies of other species as well as additional information and molecular techniques for chromosome analyses are expected to clarify and explain the reasons to support the karyotype polymorphism and chromosome evolution in these fishes.

\section{ACKNOWLEDGEMENTS}

This research supported by Department of Biology, Faculty of Science and Technology, Muban Chombueng Rajabhat University and Toxic Substances in Livestock and Aquatic Animals Research Group, Khon Kaen University. We would like to thanks Department of Biology, Faculty of Science, Khon Kaen University for accuracy check of report and valuable help.

\section{REFERENCES}

Aguilar, C.T., Oliveira-Correa, M.M., and Galetti Jr., P.M. 1998. Chromosome associations by centromeric heterochromatin in marine fishes. Journal of Chromatographic Science. 2: 73-76.

Allen, G.R. 1991. Damselfishes of the World. Hongkong: Mergus Press.

Allen, G.R. 1997. Tropical reef fishes of Thailand. Bangkok: Asia Books.

Alvarez, M.C., Cano, J., and Thode, G. 1980. DNA content and chromosome complement of Chromis chromis (Pomacentridae, Perciformes). Caryologia 33: 267-274. https://doi.org/10.1080/00087114.1980.10796 839

Arai, R. 2011. Fish karyotypes: a check list. Tokyo: Springer Japan.

Arai, R., and Inoue, M. 1976. Chromosomes of seven species of Pomacentridae and two species of Acanthuridae from Japan. Bulletin of the National Science Museum. 2: 73-78.

Getlekha, N., Molina, W.F., Cioffi, M.B., Yano, C.F., Maneechot, N., Bertollo, L.A.C., Supiwong, W., and Tanomtong, A. 2016. Repetitive DNAs highlight the role of chromosomal fusions in the karyotype evolution of Dascyllus species (Pomacentridae, Perciformes). Genetica. 144: 203-211. https://doi.org/10.1007/s10709-016-9890-5

Getlekha, N., Supiwong, W., Yeesin, P., Pengseng, P., Kasiroek, W., and Tanomtong, A. 2017. Chromosomal characteristics of the three-spot damselfish, Dascyllus trimaculatus (Perciformes, Pomacentridae) in Thailand. Cytologia. 82: 51-57. https://doi.org/10.1508/cytologia.82.51

Goodbred, C.O., and Graves, J.E. 1996. Genetic relationships among geographically isolated populations of bluefish (Pomatomus saltatrix). Marine and Freshwater Research. 47: 347-355. https://doi.org/10.1071/ MF9960347 
Hardie, D.C., and Hebert, P.D.N. 2004. Genome-size evolution in fishes. Canadian Journal of Fisheries and Aquatic Sciences. 61: 1636-1646. https://doi.org/10.1139/f04-106

Howell, W.M., and Black, D.A. 1980. Controlled silver-staining of nucleolus organizer regions with a protective colloidal developer: A 1-step method. Experientia. 36: 1014-1015. https://doi.org/10.1007/BF01953855

Kashiwagi, E., Takai, A., and Ojima, Y. 2005. Chromosomal distribution of constitutive heterochromatin and nucleolus organizer regions in four Dascyllus fishes (Pomacentridae, Perciformes). Cytologia. 70: 345-349.

Kasiroek, W., Luangoon, N., Supiwong, W., Tengjaroenkul, B., Pinthong, K., and Tanomtong, A. 2017. First report of chromosome analysis of two dragonets (Perciformes, Callionymidae). Cytologia. 82: 59-65. https:// doi.org/10.1508/cytologia.82.59

Molina, W.F., and Galetti Jr., P.M. 2002. Robertsonian rearrangements in the reef fish Chromis (Perciformes, Pomacentridae) involving chromosomes bearing5S rRNA genes. Genetics and Molecular Biology. 25: 373-377. https://doi.org/10.1590/S1415-47572002000400004

Nelson, J.S. 2006. Fishes of the world. $4^{\text {th }}$ ed. New York: John Wiley and Sons, Inc.

Ohno, S. 1970. Evolution by gene duplication. New York: Springer Verlag.

Ojima, Y. 1983. Fish cytogenetics. In: Sharma, A.K., and Sharma, A., editors. Chromosomes in evolution of eukaryotic groups. Vol. I. CRC Press. p. 111-145.

Ojima, Y., and Kashiwagi, E. 1981. Chromosomal evolution associated with Robertsonian fusion in the genus Dascyllus (Chrominae, Pisces). Proceeding of the Japan Acadamy, Series B. 57: 368-370. https://doi.org/ 10.2183/pjab.57.368

Rooney, D.E. 2001. Human cytogenetics: constutitional analysis: a Practical Approach. Oxford: Oxford University Press.

Shulman, M.A., and Bermingham, E. 1995. Early life histories, ocean currents, and the population genetics of Caribbean reef fishes. Evolution. 49:897910. https://doi.org/10.2307/2410412

Supiwong, W., Boonsuk, J., Jantarat, S., Suvarnaraksha, A., Pengseng, P., and Tanomtong, A. 2017. The first chromosomal characteristics of nucleolar organizer regions and karyological analysis of two chaetodontid fishes (Perciformes, Chaetodontidae). Cytologia. 82: 33-39. https://doi.org/ 10.1508/cytologia.82.33

Takai, A., and Ojima, Y. 1987. Comparative studies of karyotypes and distributions of nucleolus organizer regions in pomacentrid fishes. I. Proceeding of the Japan Acadamy, Series B. 63: 17-20.

Takai, A., and Ojima, Y. 1995. Chromosome evolution associated with Robertsonian rearrangements in pomacentrid fish (Perciformes). Cytobios. 84: 103-110. 
Takai, A., and Ojima, Y. 1999. Constitutive heterochromatin distribution in the chromosomes of pomacentrid fishes (Perciformes). Cytologia. 64: 87-91.

Tanomtong, A. 2011. Cytogenetics. Department of Biology, Faculty of Science, Khon Kaen University. Thailand.

Turpin, R., and Lejeune, J. 1965. Les chromosomes humains. Paris: GauthierVillars.

Ward, R.D. 1995. Population genetics of tunas. Journal of Fish Biology. 47: 259280.

White, M.J.D. 1973. Animal cytology and evolution. Cambridge: Cambridge University Press. 